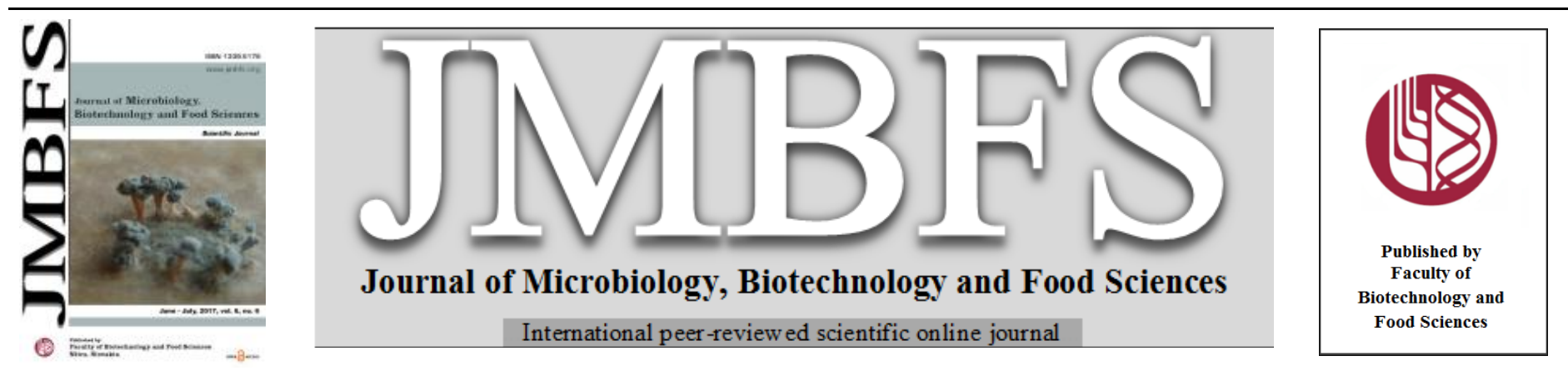

\title{
THE EFFECT OF ADDED PUMPKIN FLOUR ON SENSORY AND TEXTURAL QUALITY OF RICE BREAD
}

\section{Vikendra Dabash ${ }^{1}$, Iva Burešová*1, Marián Tokár², Michaela Zacharová1, Robert Gál ${ }^{1}$}

Address(es): doc. RNDr. Iva Burešová, Ph.D.,

${ }^{1}$ Tomas Bata University in Zlín, Faculty of Technology, Department of Food Technology, nám. T. G. Masaryka 5555, 76001 Zlín, Czech Republic, phone number: + 420576033333.

${ }^{2}$ Slovak University of Agriculture, Faculty of Biotechnology and Food Sciences, Department of Storing and Processing of Plant Products, Tr. A. Hlinku 2, Nitra, Slovak Republic.

*Corresponding author: buresova@ft.utb.cz

doi: $10.15414 /$ jmbfs.2017.6.6.1269-1271

\section{ARTICLE INFO}

Received 16. 2. 2017

Revised 15. 3. 2017

Accepted 3. 5. 2017

Published 1. 6. 2017

Regular article

open $\partial_{\text {Access }}$

\section{ABSTRACT}

The impact of added pumpkin flour $(1-10 \mathrm{~g} / 100 \mathrm{~g})$ on sensory and textural quality of rice bread was studied on rice biologically leavened rice bread. Specific volume, baking loss, crumb springiness, cohesiveness and resilience decreased with increasing amount of pumpkin flour. The opposite trend was found in crumb hardness and chewiness. Color measurements revealed that the lightness decreased and the greenness increased with increasing amount of pumpkin flour. Bread crumb and crust characteristics were not significantly impacted by the amount of added pumpkin flour. Additionally, the bread taste and flavor were decreased in breads with 8 $10 \mathrm{~g} / 100 \mathrm{~g}$ of added pumpkin flour, resulting in their lower overall acceptability. Weak impact of added pumpkin flour on sensory evaluation of rice bread may be related to a reduced amount of the panelists involved in this study. The addition of $1-7 \mathrm{~g} / 100 \mathrm{~g}$ of pumpkin flour seems to be applicable to rice bread production. More extensive study will, however, be performed to describe the impact of added pumpkin flour on sensory quality of rice bread in more details.

Keywords: Gluten-free, fortification, crumb quality

\section{INTRODUCTION}

The nutritional quality of gluten-free (GF) breads is often decreased by low protein and fiber contents (Rosell et al., 2001). It may be increased by the addition of nutritionally valuable ingredients. Pumpkin (Cucurbita moschata) flour is known to be rich in carotene, pectin, minerals, vitamins and other substances beneficial to health such as phenolic phytochemicals (Ptitchkina $\boldsymbol{e}$ al., 1998; Kwon et al., 2007; Dhiman et al., 2009). Pumpkin has, moreover, potential to improve bland taste of rice bread due to its highly pleasure flavor and sweet taste. Additionally, pumpkin seeds proteins are known to increase in vitro protein digestibility of gluten free bread (El-Soukkary, 2001), which may also positively impact bread quality. Pumpkin flour is one of the processed products of pumpkin fruit, which can be easily stored for long time and conveniently used in manufacturing of formulated foods. Pumpkin flour could be used to supplement cereal flours in bakery products to improve nutritional, physical and sensory qualities of these products (Chi-Ho et al., 2002; See et al., 2007). The impact of pumpkin flour addition on nutritional quality of wheat bread was previously studied by See $\boldsymbol{e t}$ al. (2007). They concluded that rising amount of pumpkin flour resulted in decrease of loaf specific volume but increase of crumb hardness. Moreover, increasing level of pumpkin flour resulted in decreasing sensory acceptability. The positive effect on loaf volume and organoleptic acceptability of bread were also reported by Ptitchkina et al. (1998).

The effect on added pumpkin flour on quality of gluten free rice bread has, however, not been described yet. Thus, the aim of this study was to investigate the impact of added pumpkin flour on sensory quality of rice bread, crumb color, as well as crumb characteristics measured by texture profile analysis. Disregarding the reduced amount of panelists involved in this study, the obtained preliminary results may indicate an applicability of pumpkin flour in gluten-free breadmaking.

\section{MATERIAL AND METHODS}

\section{Flours}

Fine rice flour was kindly provided by Adveni Medical, spol. s r.o. Brno, Czech Republic.

\section{Bread preparation}

A formula for dough preparation consisted of rice flour (100 g), water (110 g), sucrose (1.86 g), salt $(1.50 \mathrm{~g})$ and yeast $(1.80 \mathrm{~g})$. The amounts of $1 \mathrm{~g}, 2 \mathrm{~g}, 3 \mathrm{~g}, 4$ $\mathrm{g}, 5 \mathrm{~g}, 6 \mathrm{~g}, 7 \mathrm{~g}, 8 \mathrm{~g} 9 \mathrm{~g}$ and $10.0 \mathrm{~g}$ of pumpkin flour were added on top of other ingredients. The amounts of the ingredients were related to $100 \mathrm{~g}$ of flour dry matter. Dry yeast was reactivated for $10 \pm 1 \mathrm{~min}$. in a sugar solution $\left(35 \pm 1{ }^{\circ} \mathrm{C}\right)$. The dough ingredients were placed into an Eta Exclusive Gratus mixer bowl (Eta, a.s. CZ) and mixed for 6 min. A $150 \mathrm{~g}$ of dough was scaled into bread pans and placed into a proofer for $20 \mathrm{~min}$. at $30 \pm 1{ }^{\circ} \mathrm{C}$ and $85 \%$ relative air humidity. The loaves were baked for $20 \mathrm{~min}$. at $180 \pm 5^{\circ} \mathrm{C}$ in an oven MIWE cube (Pekass s.r.o. Plzeň, CZ). After baking, the breads were stored at room temperature for 2 $\mathrm{h}$, and then analyzed. Each test was performed on dough samples prepared at least in three replicates. The given results are represented as mean values.

\section{Textural properties of bread}

Textural properties of bread crumb were measured using texture profile analysis (TPA) on a texture analyzer TA.XT plus (Stable Micro Systems Ltd., UK). TPA was performed on samples $35 \mathrm{~mm}$ in diameter and $10 \mathrm{~mm}$ in height obtained from the center of each loaf. The sample was placed onto the analyzer base and squeezed twice to $4 \mathrm{~mm}$ with the $75.0 \mathrm{~mm}$ diameter cylinder probe $\mathrm{P} / 75$. Test speed of probe was $1.00 \mathrm{~mm} / \mathrm{s}$. The crumb parameters (hardness, stickiness, elasticity, cohesiveness and chewiness) were determined using Exponent Lite software.

\section{Sensory evaluation}

The breads were subjected to sensory evaluation by a panel of 10 department staff and students, both male and female between the ages of 19 - 50 years. A nine point hedonic scale was used to evaluate the characteristics of bread crumb and crust. Sensory score range from 1: dislike extremely to 9: like very much was used. An extensive sensory evaluation performed by higher number of panelists will be performed to support the preliminary results obtained in this study. 


\section{Statistical analysis}

The results were statistically analyzed using analysis of variance (ANOVA). The differences were tested on $\alpha=0.05$ significance level using Fisher LSD test Statistical analysis was accomplished using Statistica CZ9.1 software (Stat Soft Ltd., CZ).

\section{RESULTS AND DISCUSSION}

Baking loss of rice bread (15\%) was decreased to $12 \%$ by the presence of pumpkin flour (Table 1). The observation may be related to high pumpkin flour ability to absorb water during dough preparation as well as during baking (Rodge et al., 2012) decreasing the amount evaporated water. The bread baking loss forms the biggest losses in the technological process. The value of baking loss of rice bread with pumpkin flour decreases compared with the control bread sample, therefore the technological bread weight losses during rice bread production using pumpkin flour could be not significant. According to the experimental results, the values of bread dry off are similar for the control and experimental bread samples.

Specific loaf volume of rice bread $(1.17 \mathrm{~g} / \mathrm{mL})$ was decreased by the presence of pumpkin flour to $1.00-1.16 \mathrm{~g} / \mathrm{mL}$, however significant $(\mathrm{P}<0.05)$ decrease was observed only in bread containing $4 \mathrm{~g} / 100 \mathrm{~g}(1.00 \mathrm{~g} / \mathrm{mL}), 5 \mathrm{~g} / 100 \mathrm{~g}(1.01 \mathrm{~g} / \mathrm{mL})$, and $10 \mathrm{~g} / 100 \mathrm{~g}(1.04 \mathrm{~g} / \mathrm{mL})$ of pumpkin flour (Table 1$)$. The reduction can be explained by high content of fiber in pumpkin flour (Wang et al., 2004) since the fiber weakens dough structure, resulting in decrease of $\mathrm{CO}_{2}$ retention in dough.

\begin{tabular}{|c|c|c|c|c|c|c|c|}
\hline $\begin{array}{l}\text { Pumpkin flour } \\
\text { addition } \\
\text { (g/100g) }\end{array}$ & $\begin{array}{c}\begin{array}{c}\text { Specific loaf } \\
\text { volume } \\
(\mathrm{mL} / \mathrm{g})\end{array} \\
\end{array}$ & $\begin{array}{c}\text { Baking } \\
\text { loss } \\
(\mathrm{g} / 100 \mathrm{~g})\end{array}$ & $\begin{array}{c}\text { Hardness } \\
(\mathbf{N})\end{array}$ & $\begin{array}{c}\text { Springiness } \\
(\%)\end{array}$ & $\begin{array}{c}\text { Cohesiveness } \\
(\%)\end{array}$ & $\begin{array}{c}\text { Resilience } \\
(\%)\end{array}$ & $\begin{array}{c}\text { Chewiness } \\
(\mathbf{N})\end{array}$ \\
\hline 0 & $1.17 \pm 0.07^{\mathrm{d}}$ & $15 \pm 1^{\mathrm{d}}$ & $36 \pm 3^{a}$ & $82 \pm 2^{\mathrm{e}}$ & $72 \pm 2^{b}$ & $41 \pm 2^{\mathrm{c}}$ & $21 \pm 1.17^{\mathrm{a}}$ \\
\hline 1 & $1.10 \pm 0.03^{\text {bcd }}$ & $14 \pm 1^{\text {cd }}$ & $43 \pm 7^{\mathrm{ab}}$ & $79 \pm 1^{\mathrm{de}}$ & $71 \pm 2^{\mathrm{ab}}$ & $40 \pm 2^{\text {bc }}$ & $24 \pm 4^{\mathrm{abc}}$ \\
\hline 2 & $1.10 \pm 0.03^{\text {bcd }}$ & $12 \pm 1^{\mathrm{abc}}$ & $43 \pm 12^{\mathrm{ab}}$ & $75 \pm 3^{\text {bcd }}$ & $71 \pm 4^{\mathrm{ab}}$ & $40 \pm 5^{\mathrm{abc}}$ & $23 \pm 5^{\mathrm{ab}}$ \\
\hline 3 & $1.10 \pm 0.09^{\mathrm{bc}}$ & $13 \pm 1^{\mathrm{abc}}$ & $44 \pm 4^{\mathrm{ab}}$ & $74 \pm 3^{\text {bcd }}$ & $69 \pm 1^{\mathrm{ab}}$ & $40 \pm 1^{\mathrm{bc}}$ & $23 \pm 2^{\mathrm{ab}}$ \\
\hline 4 & $1.00 \pm 0.10^{\mathrm{a}}$ & $12 \pm 1^{\text {abc }}$ & $62 \pm 5^{\text {cd }}$ & $75 \pm 3^{\text {bcd }}$ & $68 \pm 1^{\mathrm{ab}}$ & $38 \pm 1^{\mathrm{abc}}$ & $32 \pm 4^{\mathrm{de}}$ \\
\hline 5 & $1.01 \pm 0.03^{\mathrm{a}}$ & $12 \pm 1^{\mathrm{abc}}$ & $53 \pm 9^{\mathrm{bc}}$ & $73 \pm 1^{\mathrm{abc}}$ & $71 \pm 7^{\mathrm{ab}}$ & $39 \pm 5^{\text {abc }}$ & $27 \pm 3^{\text {bcd }}$ \\
\hline 6 & $1.16 \pm 0.08^{\mathrm{cd}}$ & $14 \pm 1^{\mathrm{cd}}$ & $39 \pm 6^{\mathrm{a}}$ & $77 \pm 2^{\text {cd }}$ & $66 \pm 2^{a}$ & $36 \pm 2^{\mathrm{a}}$ & $20 \pm 3^{\mathrm{a}}$ \\
\hline 7 & $1.13 \pm 0.04^{\text {cd }}$ & $13.0 \pm 0.5^{\text {abc }}$ & $68 \pm 10^{\mathrm{d}}$ & $70 \pm 3^{a}$ & $66 \pm 3^{a}$ & $36 \pm 3^{\mathrm{ab}}$ & $31 \pm 7^{\mathrm{de}}$ \\
\hline 8 & $1.11 \pm 0.04^{\mathrm{bcd}}$ & $14.0 \pm 0.2^{\mathrm{bc}}$ & $61 \pm 10^{\text {cd }}$ & $71 \pm 5^{\mathrm{ab}}$ & $70 \pm 3^{\mathrm{ab}}$ & $39 \pm 2^{\mathrm{abc}}$ & $30 \pm 6^{\text {cde }}$ \\
\hline 9 & $1.11 \pm 0.04^{\mathrm{bcd}}$ & $13 \pm 2^{\text {abc }}$ & $71 \pm 10^{\mathrm{d}}$ & $73 \pm 7^{\mathrm{abc}}$ & $66 \pm 6^{\mathrm{a}}$ & $37 \pm 5^{\mathrm{ab}}$ & $34 \pm 6^{\mathrm{e}}$ \\
\hline 10 & $1.05 \pm 0.05^{\mathrm{ab}}$ & $13 \pm 2^{\text {abc }}$ & $60 \pm 4^{\mathrm{cd}}$ & $75 \pm 5^{\mathrm{cd}}$ & $68 \pm 2^{\mathrm{ab}}$ & $37 \pm 2^{\mathrm{ab}}$ & $31 \pm 3^{\mathrm{de}}$ \\
\hline
\end{tabular}

Crumb hardness is commonly used as an indicator of bread staling, and it is negatively co-related with bread quality (Wang $\boldsymbol{e t}$ al., 2007). The hardness of rice bread rose with increasing amount of added pumpkin flour. Hardness of rice bread $(35 \mathrm{~N})$ was increased by the presence of pumpkin flour, however significant $(\mathrm{P}<0.05)$ increase was observed only in the presence of $6 \mathrm{~g} / 100 \mathrm{~g}$, $(38 \mathrm{~N}), 2 \mathrm{~g} / 100 \mathrm{~g}(42 \mathrm{~N})$ and $1 \mathrm{~g} / 100 \mathrm{~g}(43 \mathrm{~N})$ of pumpkin flour. Additionally, the rising amount of added pumpkin flour amount caused the creation of darker and greener crumb (Table 2).

Table 2 The impact of added pumpkin flour on crumb lightness $L^{*}$, red/green coordinate $a^{*}$, yellow/blue coordinate $b^{*}$

\begin{tabular}{lccc}
\hline $\begin{array}{l}\text { Pumpkin flour } \\
\text { addition } \\
(\mathbf{g} / \mathbf{1 0 0 g})\end{array}$ & $\mathbf{L}^{*}$ & $\mathbf{a}^{*}$ & $\mathbf{b}^{*}$ \\
\hline 0 & $79.4 \pm 0.6^{\mathrm{f}}$ & $-0.07 \pm 0.08^{\mathrm{g}}$ & $14 \pm 0.3^{\mathrm{a}}$ \\
\hline 1 & $76.8 \pm 0.9^{\mathrm{e}}$ & $-0.87 \pm 0.05^{\mathrm{f}}$ & $15 \pm 0.1^{\mathrm{b}}$ \\
\hline 2 & $76 \pm 2^{\mathrm{e}}$ & $-1.00 \pm 0.2^{\mathrm{f}}$ & $15 \pm 0.3^{\mathrm{b}}$ \\
\hline 3 & $74.6 \pm 0.5^{\mathrm{d}}$ & $-2.00 \pm 0.1^{\mathrm{e}}$ & $16 \pm 0.3^{\mathrm{c}}$ \\
\hline 4 & $73.1 \pm 0.6^{\mathrm{c}}$ & $-2.3 \pm 0.1^{\mathrm{de}}$ & $17 \pm 1^{\mathrm{cd}}$ \\
\hline 5 & $70 \pm 1^{\mathrm{b}}$ & $-2.6 \pm 0.2^{\mathrm{bc}}$ & $19 \pm 1^{\mathrm{e}}$ \\
\hline 6 & $73.1 \pm 0.6^{\mathrm{c}}$ & $-2.5 \pm 0.1^{\mathrm{cd}}$ & $17 \pm 1^{\mathrm{d}}$ \\
\hline 7 & $72.6 \pm 0.6^{\mathrm{c}}$ & $-2.3 \pm 0.3^{\mathrm{d}}$ & $18 \pm 1^{\mathrm{e}}$ \\
\hline 8 & $70.0 \pm 0.6^{\mathrm{b}}$ & $-3.0 \pm 0.3^{\mathrm{a}}$ & $19 \pm 1^{\mathrm{e}}$ \\
\hline 9 & $69.5 \pm 0.7^{\mathrm{b}}$ & $-3.1 \pm 0.2^{\mathrm{a}}$ & $19 \pm 1^{\mathrm{e}}$ \\
\hline 10 & $67.7 \pm 0.8^{\mathrm{a}}$ & $-2.8 \pm 0.4^{\mathrm{ab}}$ & $20 \pm 1^{\mathrm{f}}$ \\
\hline & & & \\
\hline
\end{tabular}

Springiness, cohesiveness, and resilience were decreased by the presence of pumpkin flour (Table 1). However significant $(\mathrm{P}<0.05)$ effect was observed only in the presence of $1-6 \mathrm{~g} / 100 \mathrm{~g}$. The observation may be related to dough weakening initiated by fiber, decreasing dough ability to trap leavening gas (Plyer, 1988).

Chewiness of rice bread $(20 \%)$ was increased by the presence of pumpkin flour to $21-33 \%$, however significant $(\mathrm{P}<0.05)$ increase were observed only in bread $1 \mathrm{~g} / 100 \mathrm{~g}, 2 \mathrm{~g} / 100 \mathrm{~g}$, and $6 \mathrm{~g} / 100 \mathrm{~g}$. Gomez et al. (2003) also showed similar trend for breads with addition of fibers since they caused an increase in chewiness of tested breads.

Crumb color was found to be darker and less acceptable in breads containing pumpkin flour (Table 2). Darkness of the crumb was, moreover, directly related to the amount of pumpkin flour. The results of texture profile analysis indicated the significant impact of added pumpkin flour on rice bread crumb. The panelists, however, did not recognize any significant differences between samples (Table 3). Only taste and flavor was decreased by the presence of 8-10 g/100 g of pumpkin flour, resulting in lower overall acceptability of these breads. The impact of the presence of pumpkin flour on sensory evaluation of rice bread was weak. However, if backed by an extensive sensory study, this could be an important positive result, since pumpkin flour may improve nutritional quality of rice bread without a declining impact on bread sensory evaluation.

Table 3 Sensory evaluation of rice bread with added pumpkin flour

\begin{tabular}{lcccccc}
\hline $\begin{array}{l}\text { Pumpki } \\
\text { n flour } \\
\text { addition } \\
(\mathbf{g} / \mathbf{1 0 0 g})\end{array}$ & $\begin{array}{c}\text { Crust } \\
\text { appearance } \\
\text { and color }\end{array}$ & $\begin{array}{c}\text { Crumb } \\
\text { appearance } \\
\text { and color }\end{array}$ & $\begin{array}{c}\text { Crumb } \\
\text { elasticity }\end{array}$ & $\begin{array}{c}\text { Crumb } \\
\text { porosity }\end{array}$ & $\begin{array}{c}\text { Taste and } \\
\text { flavor }\end{array}$ & $\begin{array}{c}\text { Overall } \\
\text { acceptability }\end{array}$ \\
\hline 0 & $7^{\mathrm{a}}$ & $5^{\mathrm{a}}$ & $4^{\mathrm{a}}$ & $4^{\mathrm{a}}$ & $6^{\mathrm{a}}$ & $6^{\mathrm{a}}$ \\
\hline 1 & $7^{\mathrm{a}}$ & $6^{\mathrm{a}}$ & $5^{\mathrm{a}}$ & $5^{\mathrm{a}}$ & $6^{\mathrm{a}}$ & $6^{\mathrm{a}}$ \\
\hline 2 & $7^{\mathrm{a}}$ & $6^{\mathrm{a}}$ & $5^{\mathrm{a}}$ & $4^{\mathrm{a}}$ & $6^{\mathrm{a}}$ & $6^{\mathrm{a}}$ \\
\hline 3 & $6^{\mathrm{a}}$ & $6^{\mathrm{a}}$ & $5^{\mathrm{a}}$ & $4^{\mathrm{a}}$ & $6^{\mathrm{a}}$ & $6^{\mathrm{a}}$ \\
\hline 4 & $7^{\mathrm{a}}$ & $6^{\mathrm{a}}$ & $5^{\mathrm{a}}$ & $4^{\mathrm{a}}$ & $6^{\mathrm{a}}$ & $6^{\mathrm{a}}$ \\
\hline 5 & $7^{\mathrm{a}}$ & $6^{\mathrm{a}}$ & $4^{\mathrm{a}}$ & $4^{\mathrm{a}}$ & $5^{\mathrm{ab}}$ & $6^{\mathrm{a}}$ \\
\hline 6 & $7^{\mathrm{a}}$ & $6^{\mathrm{a}}$ & $5^{\mathrm{a}}$ & $5^{\mathrm{a}}$ & $5^{\mathrm{ab}}$ & $6^{\mathrm{a}}$ \\
\hline 7 & $6^{\mathrm{a}}$ & $6^{\mathrm{a}}$ & $5^{\mathrm{a}}$ & $5^{\mathrm{a}}$ & $6^{\mathrm{a}}$ & $6^{\mathrm{a}}$ \\
\hline 8 & $7^{\mathrm{a}}$ & $5^{\mathrm{a}}$ & $5^{\mathrm{a}}$ & $5^{\mathrm{a}}$ & $4^{\mathrm{b}}$ & $5^{\text {ab }}$ \\
\hline 9 & $6^{\mathrm{a}}$ & $6^{\mathrm{a}}$ & $5^{\mathrm{a}}$ & $5^{\mathrm{a}}$ & $4^{\mathrm{b}}$ & $5^{\text {b }}$ \\
\hline 10 & $7^{\mathrm{a}}$ & $5^{\mathrm{a}}$ & $5^{\mathrm{a}}$ & $4^{\mathrm{a}}$ & $4^{\mathrm{b}}$ & $4^{\mathrm{b}}$ \\
\hline
\end{tabular}




\section{CONCLUSION}

The addition of pumpkin flour to rice flour at different levels modified the textural properties of the enriched breads. The impact on sensory evaluation was, however, weak. Pumpkin flour seems to be able to improve rice bread quality. An extensive sensory study is, however, necessary to back these preliminary results.

Acknowledgments: The research was supported by IGA/FT/2017/004.

\section{REFERENCES}

Dhiman, A. K., Sharma, K. D., \& Attri, S. (2009). Functional constituents and processing of pumpkin: a review. Journal of Food Science and Technology (Mysore), 46(5), 411-417.

El-Soukkary, F. A. H. (2001). Evaluation of pumpkin seed products for bread fortification. Plant Foods for Human Nutrition, 56(4), 365-384.

Gómez, M., Ronda, F., Blanco, C. A., Caballero, P. A., \& Apesteguía, A. (2003).

Effect of dietary fibre on dough rheology and bread quality. European Food Research and Technology, 216(1), 51-56. http://dx.doi.org/10.1007/s00217-0020632-9

Kwon, Y. I., Apostolidis, E., Kim, Y. C., \& Shetty, K. (2007). Health benefits of traditional corn, beans, and pumpkin: in vitro studies for hyperglycemia and hypertension management. Journal of Medicinal Food,10(2), 266-275. http://dx.doi.org/10.1089/jmf.2006.234.

Chi-Ho, L., Cho, J. K., Lee, S. J., \& Koh, W. (2002). Enhancing (Beta)-carotene content in Asian noodles by adding pumpkin powder. Cereal Chemistry, 79(4), 593.

Player, E. J. (1988). Baking science and technology. Merrian: Sosland publishing Co.

Ptitchkina, N. M., Novokreschonova, L. V., Piskunova, G. V., \& Morris, E. R (1998). Large enhancements in loaf volume and organoleptic acceptability of wheat bread by small additions of pumpkin powder: possible role of acetylated pectin in stabilising gas-cell structure. Food Hydrocolloids, 12(3), 333-337. http://dx.doi.org/10.1016/S0268-005X(98)00024-1

Rodge, A. B., Sonkamble, S. M., Salve, R. V., \& Hashmi, S. I. (2012). Effect of hydrocolloid (guar gum) incorporation on the quality characteristics of bread. Journal of Food Processing and Technology, 3(2), 1-7. http://dx.doi.org/10.4172/2157-7110.1000136

Rosell, C. M., Rojas, J. A., \& De Barber, C. B. (2001). Influence of hydrocolloids on dough rheology and bread quality. Food Hydrocolloids, 15(1), 75-81.

See, E. F., Wan Nadiah, W. A. \& Noor Azizh, A. A. (2007). Physico-chemical and sensory evaluation of breads supplemented with pumpkin flour. ASEAN Food Journal 14(2): 123-130.

Wang, R., \& Zhou, W. (2004). Stability of tea catechins in the breadmaking process. Journal of Agricultural and Food Chemistry, 52(26), 8224-8229. http://dx.doi.org/10.1021/jf048655x.

Wang, R., Zhou, W. B., \& Isabelle, M. (2007). Comparison study of the effect of green tea extract on the quality of bread by instrumental analysis and sensory evolution. Food Research International, 40(4), 470-479. 